\title{
IDIOM AS A TRANSLATION TECHNIQUE: A THEORETICAL POSTULATE
}

\author{
Lucyna Harmon ${ }^{1}$ \\ 1-University of Rzeszów, Rzeszów, Poland
}

\begin{abstract}
In translation studies, the idiom is usually viewed as an important constitutive component of the source text and a possible translation problem. Several strategies and techniques of rendering idioms have been developed and discussed, and a plethora of research is focused on the ways in which selected source text idioms are rendered in the target texts. However, despite the fact that idioms frequently appear in target texts as counterparts of non-idiomatic source text expressions, the idiom has not found recognition as a valid translation technique so far and is not listed as such in relevant literature. In this paper, I will argue that it deserves this status. Although the research is based upon pure idioms, the validity of the postulate can be claimed for other types of idioms too. The material analysed was retrieved from the novels The great Gatsby by F.S. Fitzgerald and Death on the Nile by A. Christie and two German renditions of each.
\end{abstract}

Keywords: Translation; Translation Technique; Translation Strategy; Idiom; Target Text

\section{A EXPRESSÃO IDIOMÁTICA COMO TÉCNICA DE TRADUÇÃO: O POSTULADO TEÓRICO}

Resumo: Nos estudos de tradução, a expressão idiomática é geralmente vista como um componente constitutivo importante do texto original e um potencial problema de tradução. Muitas estratégias e técnicas para tradução de expressões idiomáticas foram desenvolvidas e discutidas, e uma enorme quantidade de pesquisa foi dedicada a como traduzir expressões idiomáticas selecionadas do texto original no texto de destino. No entanto, embora expressões idiomáticas frequentemente apareçam 
nos textos de destino como equivalentes a expressões não-diomáticas do texto original, a expressão idiomática ainda não foi reconhecida como uma tradução vinculativa e não é mencionada nesta forma na literatura dedicada. Neste artigo, argumentarei a favor de conceder esse status à expressão idiomática. Embora esta pesquisa seja baseada em expressões idiomáticas puras, o postulado aqui formulado pode ser estendido a outros tipos de idiomas. O material linguístico analisado aqui vem do romance $O$ Grande Gatsby de F.S. Fitzgerald e A Morte no Nilo de A. Christie e de duas traduções em alemão de cada um.

Palavras-chave: Tradução; Técnica de Tradução; Estratégia de Tradução; Expressão Idiomática; Texto de Destino

\section{Phraseme as a Linguistic Phenomenon}

In linguistics, a phraseme is comprehended as a socially fixed or relatively fixed combination/sequence of words which is typically applied and comprehended as a whole. The basic classification introduced by Vinogradov in 1947 is still valid (Burger et al. 4), despite the changes in respective terminology. Since Vinogradov's work (Russkij jazyk: grammatičeskoe učene $o$ slove) has never been translated into English, his concepts and ideas having been dissiminated in translation by other scholar, any reference to Vinogradov's terms here comes down to their English renditions, as established in the English-language presentations of his concept (e.g. Cowie Phraseology. Theory, Analysis and Application; Horwath Phraseology in English Academic Writing: some implications for language learning and dictionary making).

Vinogradov referred to what is now called a phraseme or a set phrase as a phraseological unit and distinguished three major types of it: phraseological fusion (nowadays known as a pure idiom), phraseological unity (today referred to as a figurative idiom) and phraseological combination (today labelled as a collocation or routine formula) (Burger et al. 14). Apart from exploration of the resources of phrasemes within individual languages, there are numerous contrastive investigations comparing phrasemes of 
two or more languages. Lexicography uses the results of these contrastive studies for compilation of bilingual or multilingual dictionaries of idioms which prove particularly useful in foreign language teaching/learning and translation.

At the same time, translation studies examines the phraseme as a specific text constituent that needs to be taken into consideration as such by the translator. The descriptive department of translation studies scrutinises the manners in which translators handle phrasemes in target texts. In a theoretical approach, the descriptions of actual translation solutions are generalised and take the shape of available options.

\section{Pure Idiom as a Translation Unit}

The controversies around the very notion of idiom will be ignored here as irrelevant for the present research. An idiom is comprehended as "[a]n expression consisting of two or more words used in a given language whose meaning cannot be simply predicted from the meanings of its constituent parts and that does not have a literal (equivalent) in another language" (Delisle et al. 144). The focus is on pure and figurative idioms as groups of words the meaning of which is either unmotivated (pure idiom) or motivated through metaphorical derivation (figurative metaphor) (Burger et al. 13). In the case of pure idioms, the meaning cannot be derived at all from the meaning of any of its individual constituents or their sum, whilst figurative idioms create an imaginary which allows us to deduce the meaning by analogy. Idiom belongs to the facultative level of language. Its meaning can be always conveyed in other words, with the use of a non-idiomatic phrase: This property coincides with a relevant feature of the Aristotelian metaphor.

As rightly observed by Baker (65), an idiom must be first recognised as such, which cannot be taken for granted since the same combinations of words may function in a language both in the literal and a conventional idiomatic meaning. It is the case whenever 
a given expression in literal comprehension makes sense and fits in a possible natural context. As an example, Baker provides, among others, the English expression to take somebody for a ride. The following word sequences (my own examples) can illustrate this phenomenon, too. They all can function as idioms but at the same time each of them can be easily embedded in a natural context where it preserves the meanings of all its individual constituents:

- to carry the can (to take responsibility for a mistake);

- to get one's feet wet (to make a first experience);

- for my money (in my opinion);

- the goose is cooked (it is too late);

- to make a bomb (to get a lot of money by doing something);

- to sit on a fence (to hesitate).

It is obvious that a translator who fails to recognise an idiom as such and renders it literally is likely to produce a funny, unintended side-effect and confusion.

\section{Idiom as a Translation Problem}

In translation studies, the idiom is perceived as a translation problem, generated through its mere presence in the source text and the need to establish a counterpart in the target text (Baker 64-71; Hejwowski 247), preferably in the shape of a synonymous target language idiom. There are several strategies of handling idioms in translation (Baker 71-78); Kwieciński 155-157; Hejwowski 253) , the choice of which depends to a large extent on the availability of an idiomatic correspondent in the target language lexicon. The translator can decide to replace the idiom with the semantically (fully or partly) equivalent target language idiom, if existent, regardless of the relation of its structure and lexical contents to the original. So, the expression to beat about/around the bush could be replaced with the German idiom um den heißen Brei herumreden (literally: 
to talk around hot pulp) even though the latter implies a factor that is missing from its English counterpart, namely fear or anxiety. In Polish, the corresponding idiom reads owijać w bawetne (literally: to wrap in cotton). However, it is only the negative form nie owijać $w$ bawetne (literally: not to wrap in the cotton) that is really used, which the translator will have to take into consideration. Another option is a non-idiomatic rendition of the meaning. It is mostly reached for if no suitable idiom exists in the target language, which cannot, though, be considered as a rule. As will be shown below, translators sometimes choose a non-idiomatic rendition despite the availability of an equivalent idiom in the target language. It is possible, too, to replace a source language idiom with a target language idiom of different meaning, which mostly happens when the priority is to preserve the original style rather than the message.

A literal translation of a pure idiom is likely to lead to a cognitive bump or produce unintended side-effects. To illustrate, the German idiom die Kirche im Dorf lassen (literally: to leave the church in the village, idiomatically: to keep a cool head), if rendered word-forword, might not only perplex but also upset a religious recipient. Like any other difficult (or awkward/ ambiguous) expression, an idiom can be omitted in that it is not translated at all or explained in unmarked words.

\section{Translation Strategy vs Translation Technique}

Most translation scholars make a distinction between a translation strategy (Delisle et al. 191; Hatim and Munday 226230), sometimes referred to as method (Vinay \& Darbelnet 31; Newmark 45-53), and a translation technique (Molina \& Hurtado Albir 499; Hejwowski 62), also known as procedure (Newmark 6893; Hatim \& Mason 26). As pointed out by Newmark (81), “[w]hile translation methods relate to whole texts, translation procedures are used for sentences and the smaller units of language". In other words, unlike translation strategies, which boil down to the 
translator's general approach to a given text and thus their task, translation procedures are identical with concrete solutions applied to particular small units of sense as text constituents.

Long before translation studies was established as a (relatively) autonomous academic discipline, the German philosopher Friedrich Schleiermacher suggested two basic opposite strategies of approaching a text in translation which are still valid, even though different labels have been attached to them since then. When Schleiermacher confronted the strategy of moving the reader toward the work with that of moving the work toward the reader (74), he anticipated what was later captured by such pairs of terms as anti-illusion vs illusion (Levý 19-20), foreignisation vs domestication (Venuti 24) or overt vs covert translation (House 5457). In their essence, all these oppositions mean source-text-oriented translation as the alternative of target-text-oriented translation or, in other words, the translator's care about faithfulness to the original text as the alternative of their care about the reader's comfort. Certainly, the abovementioned basic approaches to a given translation task are not the only recognised translation strategies: In order to be realised, they require some more specific ones, like adaptation, literal translation or text type change, text modification (Delisle et al. 192).

Regarding the purposes of this paper, special attention should be paid to compensation, which is qualified as a translation strategy/ method (Newmark 49; Hatim \& Munday 31), Hatim \& Mason 37) or translation technique/procedure (Delisle et al. 191, Molina \& Hurtado Albir 500). I maintain that (1) a distinction between a translation strategy and technique/procedure is vital and (2) compensation can only pass for the former. Please note that compensation in translation means introducing in the target text a specific type of expression (like a wordplay or metaphor) which could not be rendered as such in another place because of the assymmetry of the two languages in question, with the aim to preserve the overall atmosphere and style of the source text. This implies that the translator must not only have studied the whole text, or at least a considerable representative part of it, before they realise the need of compensation but also 
have performed a part of translation work. Similarly, a researcher who investigates and/or evaluates a translation must have examined the same in order to recognise cases of compensation and thus compensation itself as a strategy, i.e. a decision applied to the text as a whole. At the same time, a translator is usually able to render an utterance taken out of any context, and a researcher can easily recognise the technique/procedure they have applied. However, nothing can be stated about a possible compensation based upon a single utterance, without reference to the text as a whole. To illustrate: In the German translation of Coetzee's novel Age of Iron, the neutral sentence At which I lost control (12) is replaced with an idiomatic expression: Da platzte mir der Kragen (19), literally: Then burst me the collar. When looking at this wording in isolation, one can only confirm the application of an idiom as a substitution of a non-idiomatic word combination. In order to find out whether it serves the purpose of compensation for a loss in translation of any original idioms, a big text portion (if not the whole text) must be examined and compared with its translation. In this particular case, the comparative analysis of about 40 percent of Coetzee's work in original and in German translation does not allow us to qualify the abovementioned translation solution as compensation since not a single case of any idioms lost in translation could be established. A translation technique/procedure can be recognised in its type for any individual linguistic unit, be it a single word, word combination or sentence, whereas a strategy can be only determined through the examination of a reliable, extensive text representation.

As mentioned before, Vinay and Darbelnet (31) and Newmark (45-53, 81-93) distinguish methods and procedures of translation. Meaning the same difference, Lörscher (76) speaks of global and local strategies, whereas Delisle et al. (191-192) discuss strategies and procedures of translation. However, in Routledge Encyclopedia of Translation Studies (edited by Baker and Saldanha) that aims in the first place to clarify and uniform the terminology, there is an article on strategy (Kearns 282-285) but no mention of translation technique/procedure. 


\section{The Absence of Idiom from the Lists of Translation Techniques}

None of the relevant lists of translation techniques/procedures (Vinay \& Darbelnet 41; Newmark 81-93, Delisle 191-192), (Molina $\&$ Hurtado Albir 509-511), includes pure idiom, which seems not justified at all. There is no reason why, for instance, a descriptive equivalent or explicitation, both applicable as successful manners of "saying the same" in a language, should be recognised as fullyfledged techniques/procedures of "saying the same" in another language (which is a common understanding of translation) and a pure idiom not.

The fact is that Newmark mentions "idiomatic translation" under his translation methods, i.e. overall translation strategies. In his words, "[i]diomatic translation reproduces the 'message' of the original but tends to distort nuances of meaning by preferring colloquialisms and idioms where these do not exist in the original" (47). This strategy may require the occasional use of a pure idiom as a translation technique that is still pending recognition as such. Similarly, Delisle et al. (144) list idiomatic translation as a translation strategy. It is is identical with Venuti's (5) invisible translator's production which reads as if it has been originally written by a native speaker of the target language.

\section{Pure Idiom as a Translation Technique: Examples}

Below, the application of pure idiom as a translation technique is evidenced in two German translations of F.S.Fitzgerald's The Great Gatsby (1926) and A.Christie's Death on the Nile (1937) The original wording is marked with $\mathrm{O}$. The symbols $\mathrm{A}$ and $\mathrm{B}$ stand for the translations, as specified in the respective sections. The original non-idiomatic expressions as well as their German counterparts are italicised in bold. If available, a corresponding English language pure idiom is indicated in square brackets. These cases seem 
particularly interesting because they evidence the original author's choice not to employ an idiom despite its availability.

More than 50 percent of both texts have been examined. As point of departure, the German translations were scrutinised for idiomatic expressions. In the next step, the latter were compared with the wording of the original text, with the purpose of identifying those without an underlying original idiomatic prototype. They are presented here in the micro-context of a sentence. The original texts were not examined for the frequency of the use of idiomatic expressions, which would be necessary if I aimed to determine whether or not the idioms identified were introduced in the function of compensation. This part of research was abandoned since the idioms can be more clearly perceived as a translation technique on the micro-level of individual utterances in comparison, without a reference to the entire text.

I am aware that a relatively large number of examples provided below might be perceived as redundant and boring. Undoubtedly, just a few of them would suffice to illustrate the use of pure idiom as a translation technique and thus support the intended postulate. However, taking full risk of facing such a reproach, I have decided not to shorten the list since I believe in a convincing power of quantity: It shows that the choice of pure idiom as a counterpart of a non-idiomatic expression in translation is not a matter of occasional accident but regular practice which deserves scholarly attention and recognition.

\section{Examples from The Great Gatsby}

A: The translation by Walter Schürenberg (1953), original spelling B: The translation by Lutz-W. Wolff (2011)

(1)

$\mathrm{O}$ : When they do get married, continued Catherine, they're going West to live for a while until it blows over. (40) 
A: Wenn sie dann heiraten«, fuhr Catherine fort, »sollen sie für einige Zeit in den Westen, bis hier Gras drüber gewachsen ist. (41)

B: Wenn sie heiraten, fuhr Catherine fort, werden sie eine Weile in den Westen ziehen, bis sich alles wieder beruhigt hat. (46)

Idiom in A: über etwas ist Gras gewachsen

Literal translation: grass has grown over something

Message: something is already forgotten, [it's all water under the bridge]

O: I was sure that they were selling something. (48)

A: Ich war sicher, daß sie irgend etwas an den Mann bringen wollten. .50

B: Ich war mir sicher, dass sie etwas zu verkaufen versuchten. (55)

Idiom in A: etwas an den Mann bringen

Literal translation: to bring something at the man

Message: to soft-sell something

O: As our credulity switched back to her she leaned forward with enthusiasm. (50)

A: Als wir nun wieder gläubig an ihren Lippen hingen, war sie entzückt und beugte sich eifrig vor. (53)

B: Als sich unsere Gutgläubigkeit wieder ihr zuwandte, beugte sie sich aufgeregt vor (58)

Idiom in A: an jemandes Lippen hängen

Literal translation: to hang on somebody's lips

Message: to listen to somebody eagerly, [to hang on somebody's lips]

(4)

$\mathrm{O}$ : It fooled me. (52)

A: Ich bin glatt darauf hereingefallen (55)

B: Hab's nicht glauben wollen. (60) 
Idiom in A: auf etwas hineinfallen

Literal translation: to fall in on something

Message: to fall for something, to be taken in by something

A: ...als hätten mich einzig und allein die Begebenheiten dreier Abende, die zudem mehrere Wochen auseinanderlagen, in Atem gehalten. (67)

B: ...als ob mich damals lediglich drei Nächte im Abstand mehrerer Wochen beschäftigt hätten.(72)

O: ...that the events of three nights several weeks apart were all that absorbed me. (62)

Idiom in A: jemandem in Atem halten

Literal translation: to keep someone in breath

Message: to occuppy someone, cause suspense

(6)

O: I liked to walk up Fifth Avenue and pick out romantic women from the crowd. (63)

A: Mit Vorliebe spazierte ich die Fifth Avenue hinauf, nahm aus der Menge diese oder jene vielversprechend aussehende Frau aufs Korn. (68)

B: Wenn ich die Fifth Avenue hinaufging, suchte ich mir in der Menge romantische Frauen heraus. (73)

Idiom in A: jemanden aufs Korn nehmen

Literal translation: to take somebody on the bead

Message: to zero in on somebody, [to draw a bead on somebody]

(7)

O: Then it was something more. (64)

A: Bald jedoch war noch etwas anderes dabei im Spiel. (69)

B: Dann wurde es etwas mehr. (74)

Idiom in A: im Spiel sein

Literal translation: to be in play

Message: to be a factor, to play a role

Cad. Trad., Florianópolis, v. 41, n 1, p. 125-147, jan-abr, 2021. 
(8)

$\mathrm{O}$ : I suppose she had begun dealing in subterfuges when she was very young. (64-65)

A: Ich vermute, daß sie bei dieser Veranlagung schon in früher Jugend krumme Wege einschlug. (70)

B: hatte deshalb schon in sehr jungen Jahren begonnen, sich

kleiner Tricks zu bedienen (74)

Idiom in A: krumme Wege gehen/einschlagen

Literal translation: to go/start going crooked ways

Message: to do/start doing wrong, [to leave the straight and narrow]

(9)

O: without a word or a gesture of exultation a new well-being radiated from him .96)

A: Ohne daß er mit einem Wort oder einer Geste seinem

Überschwang Luft machte, ging eine ganz neue strahlende

Glückseligkeit von ihm aus und verbreitete sich im Raum. ».(105)

B: ohne ein Wort oder eine Geste des Jubels strahlte ein neues

Wohlbefinden von ihm aus

(109)

Idiom in A: einer Sache Luft machen

Literal translation: to make air to something

Message: to display something (an emotion)

(10)

$\mathrm{O}$ : He went into an immediate decline. (95)

A: Es ging von da an rapide mit ihm bergab. (104)

B: ...stattdessen begann ein sofortiger Abstieg. (108)

Idiom in A: es geht mit etwas bergab

Literal translation: it goes mountain down with something

Message: something declines, [something goes down hill]

O: Do you mean you've been thinking over what I proposed the other night? (97) 
A: Heißt das, Sie haben sich meinen Vorschlag von gestern abend durch den Kopf gehen lassen? (106)

B: Wollen Sie damit sagen, dass Sie sich überlegt haben, was ich Ihnen neulich Nacht vorgeschlagen habe? (111)

Idiom in A: sich etwas durch den Kopf gehen lassen

Literal translation: to let something go through one's head

Message: to think about something

O: Recovering himself in a minute...(99)

A: In der nächsten Minute hatte er sich jedoch schon wieder gefaßt. (108)

B: Nach einer Minute hatte er sich wieder im Griff. (113)

Idiom in B: sich (etwas) im Griff haben

Literal translation: to have oneself (something) in grip

Message: to have (something) under control, to come to grips with something

O: what remained of the millions went intact to Ella Kaye. (107)

A: Jedenfalls ging das, was von den Millionen übrig war, in

Bausch und Bogen an Ella Kaye. (118)

B: was von Codys Millionen übrig war, ging komplett an Ella Kaye. (123)

Idiom in A: in Bausch und Bogen

Literal translation: in wad and bow

Message, wholesale, complete, lock, stock and barrel

\section{Comment}

As can be seen, only one example of substituting a nonidiomatic expression with an idiomatic counterpart was identified in the more recent (2011) German translation (excerpt 12), Certainly, this finding could be related to and even set against the 
part of Retranslation Hypothesis (Berman 1) which claims that the subsequent renditions get closer to the letter and style of the original than the first one. However, the present research is not meant to follow this line. What matters for our purposes here is that even the one example from Wolff's translation entitles us to confirm the idiomatic expression as a translation technique, i.e. the way the translator chose to render a non-idiomatic wording, having alternative options at his disposal.

\section{Examples from Death on the Nile}

A: The translation by Susanne Lepsius (1966), original spelling

B: The translation by Pieke Biermann (1999)

(1)

O: I don't know how she"s managed to get along the last two years. (15)

A: Ich frage mich, wie sie sich die letzten zwei Jahre über

Wasser gehalten hat. (6)

B: Ich weiß gar nicht, wie sie die letzten zwei Jahre über die

Runden gekommen ist. (10)

Idiom in A: sich über Wasser halten

Literal translation: to hold oneself above water

Message: to manage with difficulty to pay one's living, [to keep the wolf from the door]

Idiom in B: über die Runden gekommen

Literal translation: come over the rounds

Message: to manage with difficulty to pay one's living, [ to make the ends meet]

O: That refusal of hers had not been at all a definite refusal. (18)

A: Der Korb, den sie ihm gegeben hatte, war keineswegs eine 
endgültige Absage. (12)

B: Ihre Weigerung, ihn zu heiraten, war nicht endgültig gewesen (...). (8)

Idiom in A: jemandem einen Korb geben

Literal translation: to give somebody a basket

Message: to turn somebody down (usually an admirer)

(3)

O: I knew you were. You wouldn't let me down. (22)

A: Ich wußte, du würdest mich nicht im Stich lassen. (11)

B: Ich wusste es. Du würdest mich nicht im Stich lassen. (16)

Idiom in A and B: jemanden im Stich lassen

Literal translation: to let somebody in sting

Message: to let somebody down, [to hang somebody out to dry]

O: we'll settle it all up. (22)

A: dann machen wir die Sache perfekt. (11)

B: wir bringen alles unter Dach und Fach.(16)

Idiom in B: etwas unter Dach und Fach bringen

Literal translation: to bring something under roof and shelf

Message: to finalize something, [to get something in the bag]

(5)

O: Mrs. Allerton was alert. (34)

A: Mrs. Allerton war auf der Hut. (20

B: Mrs. Allerton war immer auf der Hut. (26)

Idiom in A and B: auf der Hut sein

Literal translation: to be on guard

Message: to be watchful, [to look out for squalls]

(6)

O: The friendship between her son and his second cousin, Joanna Southwood, always irritated her. (31)

A: Die Freundschaft zwischen ihrem Sohn und seiner Kusine 
zweiten Grades irritierte sie. (21)

B: Die Freundschaft zwischen ihrem Sohn und seiner Cousine zweiten Grades, Joanna Southwood, war ihr ein Dorn im Auge. (27)

Idiom in B: ein Dorn in jemandes Auge sein

Literal translation: to be a thorn in somebody's eye

Message: to bother somebody, [to be a thorn in somebody's flesh/ side]

O: Seems he was pretty badly hit when Linnet Ridgeway turned him down. (37)

A: anscheinend hat es ihn hart getroffen, daß Linna Ridgeway ihn hat fallenlassen. (22)

B: War wohl ein schwerer Schlag für ihn, dass Linnet Ridgeway ihm den Laufpass gegeben hat. (28)

Idiom in B: jemandem einen Laufpass geben

Literal translation: to give somebody a running ticket

Message: to turn somebody down (usually an admirer), [to give somebody their marching orders]

O: I didn't know old Wode was such a favourite of yours. (39) A: Ich wußte gar nicht, daß der alte Wode bei dir so hoch im Kurs steht. (24)

B: Ich wusste gar nicht, dass der alte Wode so einen Stein bei dir im Brett hat. (30)

Idiom in A: hoch im Kurs stehen

Literal translation: to stand high in exchanging rate

Message: to be highly regarded, to be in somebody's good books, to be well in with somebody

Idiom in B: bei jemandem einen Stein im Brett haben Literal translation: to have a stone in the board with somebody Message: to be highly appreciated by somebody 
(9)

O: I hope I can pull it off. (47)

A: Hoffentlich gelingt's mir. (30)

B: Ich will hoffen, dass ich das Ding geschaukelt kriege. (38)

Idiom in B: etwas geschaukelt kriegen

Literal translation: to get a thing swung

Message: to be successful in an attempt

O: Cornelia was not good at snubbing people (131)

A: Im Gegensatz zu Miss van Schuyler lag ihr jeder Gedanke an Arroganz völlig fern.(89)

B: Cornelia konnte niemandem die kalte Schulter zeigen. (108)

Idiom in B: jemandem die kalte Schulter zeigen

Literal translation: to show somebody a cold shoulder, to show somebody the cold shoulder

Message: to reject somebody, [to give somebody the cold shoulder]

(11)

O: We're both agreed that we won't try to dodge her any more. (146)

A: Wir beschlossen, Jackie von nun an nicht mehr aus dem Wege zu gehen. (100)

T: Wir haben beide beschlossen, wir wollen gar nicht mehr

versuchen, ihr aus dem Weg zu gehen. (122)

Idiom in A and B: jemendem aus dem Wege gehen

Literal translation: to go somebody out of the way

Message: to avoid somebody

O: Mrs Allerton had grown to like the little man very much. (157)

A: Mrs. Allerton empfand für den kleinen Mann eine aufrichtige Sympathie. (108) 
B: Mrs. Allerton war der kleine Mann regelrecht ans Herz gewachsen. (130)

Idiom in B: jemandem ans Herz wachsen

Literal translation: to grow somebody on the heart

Message: to become somebody's favourite, [to grow dear on somebody's heart]

O: His calls became slightly absent-minded. (173)

A: Sein Spiel wurde immer unaufmerksamer. (119)

B: Er war nicht mehr richtig bei der Sache. (144)

Idiom in B: nicht bei der Sache sein

Literal translation: not to be by the thing

Message: not to be focused, not to keep on task

O: do you think you can treat me as you have done and get away with it? (178)

A: »meinst du wirklich, du kommst ungeschoren davon nach allem, was du mir angetan hast? (123)

B: «hast du geglaubt, du kannst so mit mir umspringen und damit durchkommen? (148)

Idiom in A: ungeschoren davon kommen

Literal translation: to get away unshorn

Message: to avoid punishment, [to get away scot-free]

O: Bessner explained Jacqueline's hysterics and the circumstances which had led Miss Bowers to take charge of her. (194)

A: Bessner berichtete von Jacquelines hysterischem Zustand und von Miss Bowers, die man zu Hilfe gerufen hatte. (134)

B: Bessner erläuterte, wie hysterisch Jacqueline gewesen war und unter welchen Umständen Miss Bowers sie unter ihre Fittiche genommen hatte. (161)

Idiom in B: jemanden unter seine Fittiche nehmen 
Literal translation: to take somebody under one's wings Message: to protect somebody

O: I think he thought if he kept quiet she might simmer down. (198)

A: Vermutlich dachte er, wenn er schwiege, würde sie sich allmählich beruhigen. (137)

B: Ich glaube, er dachte, wenn er den Mund hält, dann kühlt sie vielleicht wieder ab.(164-165)

Idiom in B: den Mund halten

Literal translation: to keep the mouth

Message: to be silent, [to keep one's mouth shut]

\section{Comment}

The comparison of the German translation shows more balance between them both than established between the two examined German renditions of The Great Gatsby. In 16 excerpts, idiomatic expressions were encountered 7 times in the older version, and 14 times in the more recent one. So, it is the latter rather than the former to which a tendency to employ idioms may be attributed.

\section{Concluding remarks}

The purpose of this study was to claim for the idiom the status of a translation technique. Two sets of examples from two English language novels were provided in order to illustrate the application of an idiom as a replacement of a plain, non-idiomatic expression in translation. Altogether, 29 excerpts from the both works were quoted. In most of them (24), one translator has chosen an idiomatic substitute whilst the other preserved the unmarkedness of 
the original wording. In five cases, both translators opted for an idiom to substitute a non-idiomatic one.

As was argued before, an idiomatic expression as a substitute of a non-idiomatic original one may occur in translation as a realisation of compensation strategy but it is not a rule. A researcher can only establish the translator's strategy on having examined and compared the complete original text and its translation or at least large representative parts of both. A technique can be recognised through a comparative examination of matching individual units of sense in micro-context. In this research, idioms in selected translations were examined in micro-contexts only and were qualified as translation techniques, hopefully, in a conclusive manner, without the intention to determine if they serve the compensation strategy 


\section{References}

Baker, Mona. In Other Words. London: Routledge, 1992.

Baker, Mona; Saldanha, Gabriela. (Eds.). Routledge Encyclopedia of Translation Studies. 2nd edition. London: Routledge, 2008.

Berman, Antoine. "La retraduction comme espace de traduction". Palimpsestes. 13, (1990): 1-7.

Burger, Harald; Dobrovolskij, Dmitrij; Kühn, Peter; Norrick, Neal R. (Eds.). Phraseologie: ein internationales Handbuch zeitgenössischer Forschung/Phraseology: an international handbook of contemporary research. Berlin: Walter de Gruyter, 2007.

Coetzee, John M. Age of Iron. New York: Penguin. 1990/1998.

Coetzee, John M. Eiserne Zeit Trans. Wulf Teichmann: Fischer. 1998/2002.

Christie, Agatha. Death on the Nile. New York: Harper Collins. 1937/1993.

Christie, Agatha. Der Tod auf dem Nil. Trans. Susanne Lepsius. Scherz,. 1966/1981.

Christie, Agatha. Der Tod auf dem Ni., Trans. Pieke Biermann. Paris: Hachette Collections, 1999/2008.

Cowie, A. P. (Ed.). Phraseology. Theory, Analysis and Application. Oxford: Oxford University Press, 1988.

Delisle, Jean; Lee-Jahnke, Hannelore; Cormier Monique. C. (Eds.). Translation Terminology. Amsterdan: John Benjamins, 1999.

Fitzgerald, Francis Scott. The Great Gatsby. New York: Penguin. 1926/1994. 
Fitzgerald, Francis Scott. Der große Gatsby. Trans. Walter Schürenberg. Zurich: Diogenes. 1953/1974.

Fitzgerald, Francis Scott. Der große Gatsby. Trans. Lutz.-W. Wolff. dtv.1926/2011.

Hejwowski, Krzysztof. Iluzja przekładu. Śląsk, 2015.

Hatim, Basil; Munday, Jeremy. Translation: an advanced resource book. London: Routledge, 2004.

Hatim, Basil; Mason, Ian. The Translator as Communicator. London: Routledge, 1997/2005.

Horwath, Peter. A. Phraseology in English Academic Writing: some implications for language learning and dictionary making. Berlin: Niemeyer, 1996.

House, Juliane. Translation Quality Assessment: Present and Past. London: Routledge, 2014.

Kearns, John. "Strategies". Routledge Encyclopedia of Translation Studies, Baker, Mona; Saldanha, Gabriela. (Eds.). Londres: Routledge, 2009. pp. 282285.

Levý, Jiří. The Art of Translation. Trans. Patrick Corness. Amsterdan: John Benjamins, [1963] 2011.

Kwieciński, Piotr. Disturbing strangeness: foreignisation and domestication in translation procedures in the context of cultural assymmetry. Torun: Edytor, 2001.

Lörscher, Wolfgang. Translation Performance, Translation Process and Translation Strategies: A Psycholinguistic Investigation. Gunter Narr, 1971.

Molina, Lucia and Hurtado Albir, Amparo. "Translation Techniques Revisited". Meta. XLVII 4, (2002): 498-512. 
Newmark, Peter. A Textbook of Translation. London: Longman Pearson Education, 1988/2003.

Schleiermacher, Friedrich. "On the different methods of translating". Translating Literature: The German Tradition from Luther to Rosenzweig. Trans. André. Lefevere. Netherlands: Van Gorcum, [1938]1977, pp. 67-89.

Venuti, Lawrence. The Translator's Invisibility. A History of Translation. London: Routledge, 1995/2014.

Vinay, Jean.-Paul; Darbelnet, Jean. Comparative Stylistics of French and English. A methodology for translation. Trans. Juan C. Sager and M.-J. Hamel. Amsterdan: John Benjamins, 1958/1995.

Vinogradov, Viktor.V. Russkij jazyk: grammatičeskoe učene o slove. Moscow: OGIZ. 1947.

Recebido em: 02/08/2020

Aceito em: 26/11/2020

Publicado em janeiro de 2021

Lucyna Harmon. E-mail: luwille@yahoo.de. ORCID: https://orcid.org/00000001-8606-3464. 